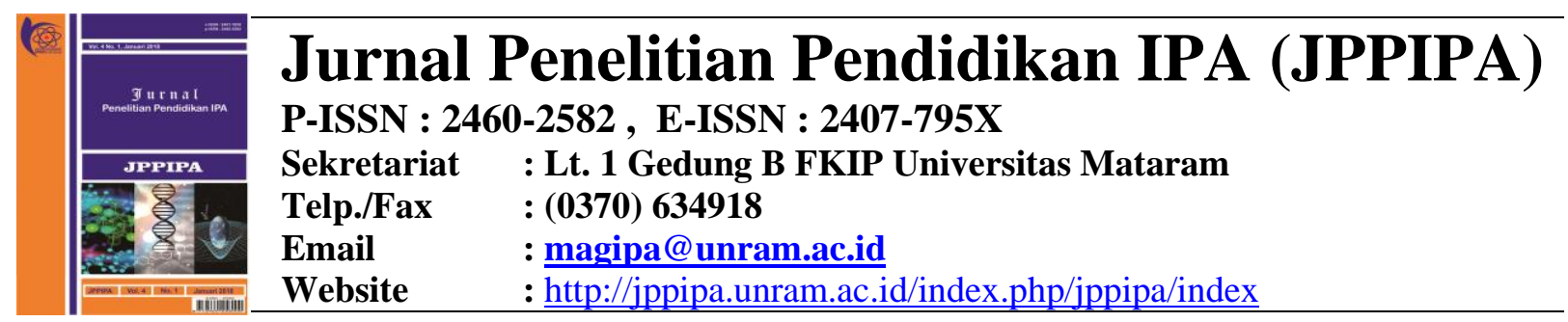

\title{
BAKTERI ENDOFIT KULIT BATANG TERAP (ARTOCARPUS ELASTICUS) DAN AKTIFITASNYA SEBAGAI ANTIBAKTERI
}

\author{
Guplin $^{1}$, Dwi Soelistya D.J. ${ }^{2}$ dan Lalu Zulkifli ${ }^{3}$ \\ Program Studi Magister Pendidikan IPA, Program Pascasarjana Universitas Mataram \\ E-mail: adlyfurqon@gmail.com
}

\begin{tabular}{|c|c|}
\hline Key Words & Abstract \\
\hline $\begin{array}{l}\text { Terap bark, } \\
\text { Endophytic } \\
\text { bacteria, } \\
\text { Identification, } \\
\text { Antibacteria }\end{array}$ & $\begin{array}{l}\text { This study aims to identify the types of endophytic bacteria on the bark of } \\
\text { terap (Artocarpus elasticus) capable of inhibiting the growth of clinical } \\
\text { isolate bacteria of Staphylococcus aureus, Escherichia coli, Salmonella } \\
\text { typhi, and Pseudomonas aeruginosa. Stages of this study were (1) isolating } \\
\text { the endophytic bacteria from the bark of terap plants (2) antibacterial test } \\
\text { (inhibition test) against clinical isolate bacteria, (3) biochemical test upon } \\
\text { endophytic isolate bacteria showing strong inhibition effect, (4) moleculer } \\
\text { identifcation upon endophytic bacteria isolate showing strong inhibition } \\
\text { effect. From this study, it was obtained } 34 \text { barks of terap isolates, and } 12 \\
\text { isolates have inhibitory effect on } S . \text { aureus. Based on 16S rRNA } \\
\text { molecular identification, the isolate of endophytic bacteria of the barks } \\
\text { were identified as Bacillus cereus, Bacillus subtilis and Bacillus } \\
\text { amyloliquefaciens. Those endophytic bacteria of Terap plants are } \\
\text { potentially to be developed as a the producer of antibacterial compounds. }\end{array}$ \\
\hline Kata Kunci & Abstrak \\
\hline $\begin{array}{l}\text { Kulit batang } \\
\text { terap, Bakteri } \\
\text { endofit, } \\
\text { identifikasi, } \\
\text { Antibakteri }\end{array}$ & $\begin{array}{l}\text { Penelitian ini bertujuan untuk mengidentifikasi jenis bakteri endofit pada } \\
\text { kulit batang tanaman terap (Artocarfus elastiscus) yang mampu } \\
\text { menghambat pertumbuhan bakteri isolat klinik Staphylococcus aureus, } \\
\text { Escherichia coli, Salmonella typhi dan Pseudomonas aeruginosa.. } \\
\text { Tahapan penelitian ini adalah (1) isolasi bakteri endofit dari kulit batang } \\
\text { tanaman terap, (2) uji antibakteri (uji daya hambat) terhadap bakteri } \\
\text { isolat klinik, (3) uji biokimia isolat bekteri endofit yang memiliki daya } \\
\text { hambat, (4) identifikasi isolat bakteri endofit yang memiliki daya hambat } \\
\text { secara molekuler. Dalam Penelitian ini diperoleh } 34 \text { isolat kulit batang } \\
\text { tanaman terap dan } 12 \text { isolat mempunyai daya hambat terhadap S. aureus. } \\
\text { Berdasarkan identifikasi molekuler dengan } 16 \mathrm{~S} \text { rRNA isolat bakteri } \\
\text { endofit kulit batang tanaman terap teridentifikasi sebagai bakteri Bacillus } \\
\text { cereus, Bacillus subtilis dan Bacillus sp. Tiga jenis bakteri endofit } \\
\text { tanaman terap ini dapat dikembangkan sebagai penghasil senyawa } \\
\text { antibakteri }\end{array}$ \\
\hline
\end{tabular}




\section{PENDAHULUAN}

Latar Belakang Indonesia dikenal mempunyai berbagai macam tanaman obat yaitu sebanyak 940 spesies yang digunakan sebagai bahan obat, tetapi baru $20-22 \%$ yang dibudidayakan dan telah diketahui khasiatnya. Sekitar $78 \%$ diperoleh melalui eksplorasi (pengambilan langsung) dari hutan (Masyhud, 2010).

Bakteri endofit merupakan bakteri saprofit yang hidup dan berasosiasi dengan jaringan tanaman tanpa menimbulkan suatu gejala penyakit pada tanaman tersebut. Dilaporkan bahwa keberadaan bakteribakteri endofit di dalam jaringan tanaman selain berperanan dalam perbaikan pertumbuhan tanaman, juga karena kemampuannya menghasilkan zat pemacu tumbuh, memfiksasi nitrogen, memobilisasi fosfat, dan juga berperanan dalam kesehatan tanaman. Bakteri endofit diduga mampu meningkatkan sistem pertahanan tanaman terhadap gangguan penyakit tanaman karena kemampuannya untuk memproduksi senyawa antimikroba, enzim, asam salisilat, etilena dan senyawa sekunder lainnya yang berperanan menginduksi ketahanan tanaman (Backman dan Sikora, 2008).

Endofit bertindak sebagai sumber yang tak terbatas untuk memproduksi senyawa berkhasiat obat. Endofit ditemukan mengandung senyawa antimikroba, antivirus, antikanker, antioksidan, antidiabetes dan immunosuppressant (Strobel, 2002). Beberapa jenis bakteri endofit diketahui mampu menghasilkan senyawa aktif yang bersifat antibiotik (Castillo et al., 2003), antimalaria (Simanjuntak et al., 2004) dan antifungi (Beck et al., 2003).

Salah satu famili tumbuhan di hutan tropis yang berpotensi sebagai sumber bahan kimia bioaktif dan jumlahnya relatif besar adalah Moraceae. Famili Moraceae adalah A. yang terdiri dari 50 spesies dan tersebar mulai dari Asia Selatan, Asia Tenggara hingga kepulauan Solomon, kepulauan Pasifik, Australia Utara dan
Amerika Tengah. Di Indonesia banyak ditemukan misalnya di pulau Kalimantan terdapat 25 spesies, 13 spesies di antaranya endemik, namun baru dua spesies yang dimanfaatkan yaitu : A. heterophyllus dan A. integer (Hakim, 2011).

Terap termasuk tanaman genus Artocarpus, berarti memiliki genus yang sama dengan sukun (A. communis), keluih A. camansi dan nangka (A. altilis). Secara morfologi terap memiliki persamaan sifat dengan keluih dan sukun. Getah terap dapat digunakan sebagai palut untuk menangkap burung, sebagai obat disentri dan daunnya jika dicampur dengan nasi digunakan sebagai obat batuk. Biji tanaman ini dapat dimakan setelah digoreng dan dibuat minyak goreng serta dapat digunakan sebagai minyak rambut wanita (Heyne, 1987)

Berdasarkan pemikiran dan kajian pustaka diatas perlu dilakukan isolasi, identifikasi bakteri endofit pada kulit batang Terap dan melakukan uji aktivitasnya sebagai anti bakteri.

\section{BAHAN DAN METODE}

Jenis penelitian eksferimental, deskriptif, eksploratif dengan cara mengisolasi, identifikasi dan uji antibakteri, bakteri endofit dari kulit batang tanaman kemudian di uji isolat bakteri endofit terhadap bakteri isolat klinik $S$. aureus, E. coli, S. typhi dan $P$. aeruginosa.

Bahan isolasi bakteri endofit adalah Alkohol 70\%, Natrium Hipoklorit $(\mathrm{NaOCl})$ $4 \%$, Aquades, kertas saring, tissue, Nutrien Agar (NA), kulit batang tanaman Terap.

Bahan uji antibakteri adalah Nutrien Broth (NB), NaCl 0,9\%, 0,5 Mc Farland, Muller Hinton Agar (MHA), bakteri uji, S. aureus, E.. coli, S.tyhpi dan P. aeruginosa, antibiotik Cyprofloxasin dan Aquades. Bahan uji Biokimia (Fisiologis) adalah media Sulfit Indol Motility (SIM) agar, reagent Hidrogen Peroksida (H2O2) 3\%, reagent dimetil-pfenildiamna hidroklorida $1 \%$, reagen kovacks, media Urea Agar miring, media 
Simmons citrate Agar, media MR-VP, reagent metil red, reagen barit $\mathrm{A}$ dan barit $\mathrm{B}, \mathrm{NaCl} 0,5 \%$, pepton $1 \%$, phenored $1 \mathrm{ml}$, glukosa $0,2 \%$, sukrosa $0,2 \%$, maltosa $0,2 \%$, manitol $0,2 \%$, laktosa $0,2 \%$, medium Triple Sugar Iron Agar (TSIA).

Bahan ekstraksi DNA adalah DNA Zol $200 \mu \mathrm{l}$, etanol $95 \% 100 \mu \mathrm{l}, 200 \mu \mathrm{l}$, Aquades $40 \mu \mathrm{l}$. Bahan Amplifikasi DNA menggunakan PCR adalah Primer 1: $63 \mathrm{f}$ (5'-CAG GCCTAA CACATG CAA GTC) $1 \mu \mathrm{l}$, Primer $2: 1387 \mathrm{r}$ (5'-GGG CGG WGT GTA CAAGGC) $1 \mu \mathrm{l}$, PCR Master Mix Solution (2x) $10 \mu \mathrm{l}$, Template DNA 1$2 \mu 1$, Aquades 6-7 $\mu 1$.

Bahan Elektroforesis adalah produk PCR $4 \mu$ l, Loading buffer (Bromphenolblue dan Cyline Cyanol), gel agarosa 2\% 0,5 gram, buffer TAE $50 \mathrm{ml}$, Etidium Bromide (EtBr) $4 \mu$ l, Marker 1000 bp DNA Ladder (Invitrogen).

\section{Isolasi bakteri endofit dari kulit batang tanaman terap}

Sampel (kulit batang) tanaman terap dalam keadaan segar dibersihkan dengan air mengalir kemudian dipotong-potong sepanjang $\pm 5 \mathrm{~cm}$. Potongan sampel tersebut kemudian disterilisasi permukaannya dengan direndam dalam alkohol $70 \%$ selama 1 menit, Natrium Hipoklorit 4\% selama 5 menit, dan dibilas dengan aquades dan dikeringkan dalam laminar air flow diletakkan diatas kertas saring. Potongan sampel yang sudah disterilisasi dipotongpotong sepanjang $0,5 \mathrm{~cm}$ pada setiap bagian sisinya kemudian ditanam (posisi berdiri) dalam media NA. Media yang sudah mengandung sampel tersebut diinkubasi pada suhu $32^{\circ} \mathrm{C}$ dan diamati setiap hari sampai ada pertumbuhan koloni. Bakteri endofit yang tumbuh, dipisahkan masing-masing koloni dan di kultur pada petri dish dan diinkubasi pada suhu $32^{\circ} \mathrm{C}$ selama 24 jam. Dilakukan pengecatan gram. Jika isolat belum murni di kultur lagi untuk diperbanyak (menggunakan slant/ media agar miring) sampai diperoleh biakan murni .

\section{Uji daya hambat}

Kultur isolate bakteri endofit diambil 2 lop/ ose dimasukkan pada medium cair $10 \mathrm{ml} \mathrm{NB}$ steril lalu di vortex. Kultur isolat bakteri endofit diinkubasi selama 24 jam pada suhu $32^{\circ} \mathrm{C}$, digoyang selama 24 jam dalam 150 putaran/menit. Kultur isolate bakteri endofit disentrifugasi pada 5000 g selama 30 menit, sehingga dihasilkan supernatant

Bakteri patogen yang sudah disegarkan dibuat pengenceran dengan mencampurkan 1 ose suspensi bakteri patogen ke dalam tabung reaksi yang telah berisi $\mathrm{NaCl} 0,9 \%$. Dihomogenkan menggunakan vortex dan kekeruhannya distandarisasi dengan konsentrasi $0,5 \mathrm{Mc}$ Farland. Larutan bakteri yang telah distandarisasi tadi, dioleskan ke media MHA dengan rata dengan menggunakan sweb dari kapas yang streril. Membuat lubang pada media MHA dengan diameter $6 \mathrm{~mm}$. Kemudian masukkan supernatant \pm $50 \mu 1$ ke dalam setiap lubang media MHA yang telah diinokulasi bakteri patogen dan Cyprofloxasin sebagai dan Aquades sebagai kontrol negatif dilakukan 3 kali ulangan

Zona hambat didapatkan dengan mengukur diameter zona yang tidak terdapat pertumbuhan bakteri isolat klinik oleh isolat bakteri endofit pada setiap sumuran.Bentuk zona hambat yang tidak beraturan, pengkurannya dilakukan dengan mengukur dimeter terpendek dan terpanjang kemudian rata-ratanya dianggap sebagai hasil pengkuran. Luas zona hambat didapatkan dengan menjumlahkan diameter zona hambat masing-masing isolat bakteri endofit sebanyak tiga kali ulangan dan menentukan rata-ratanya

\section{Uji Fisiologi (Biokimia)}

Uji motilitas uji katalase uji indol uji hidrolisis urea uji simmon sitrat uji metil red-voges proskauer (mr-vp) uji metil red uji hidrolisis pati menggunakan metod (Raihana, 2011). Uji fermentasi karbohidrat (Adawiah, 2006) dan Uji TSIA 
(Triple Sugar Iron Agar)

(Sardiani et al., 2015).

\section{Ekstraksi DNA}

Ekstrasi DNA dilakukan dengan mengambil satu (1) ose sampel ditambah $200 \mu 1$ DNA Zol di vortex selama 1 menit, ditambahkan etanol $100 \%$ sebanyak $100 \mu$ l dan didiamkan selama 5 menit. Disentrifugasi $4000 \mathrm{~g}$ selama 4 menit kemudian dicuci sebanyak 2 kali dengan etanol $80 \%$ sebanyak $200 \mu 1$ dan didiamkan selama 4 menit. Disentrifugasi pada $4000 \mathrm{~g}$ selama 2 menit. Dilarutkan pada aquades $40 \mu 1$ dan disimpan pada $-20^{\circ} \mathrm{C}$ sampai saat digunakan.

\section{Amplifikasi gen 16S-rRNA dengan PCR}

Primer Universal 16S-rRNA yang digunakan adalah Primer 63f (5'-CAG GCCTAA CACATG CAA GTC) dan 1387r (5'-GGG CGG WGT GTA CAAGGC) . Dalam tabung PCR dimasukkan 2x PCR Master Mix Solution $10 \mu \mathrm{l}$, Template DNA 1-2 $\mu$ l, Primer 63f $1 \mu \mathrm{l}$, Primer 1387r $1 \mu \mathrm{l}$, Aquades 6-7 $\mu \mathrm{l}$. Selanjutnya tabung PCR dimasukkan dalam mesin PCR (Bio Rad). Pada tahap elektroforesis, sebanyak $4 \mu \mathrm{l}$ produk PCR ditambahkan dengan $2 \mu$ Loading buffer (Bromphenolblue dan Cyline Cyanol). Di elektroforesis pada $2 \%$ gel agarose dalam buffer TAE (0,5 gram agarose ditambah dengan $50 \mathrm{ml}$ TAE) yang telah di isi sebanyak $4 \mu \mathrm{l}$ etidium bromide (EtBr). Elektroforesis dilakukan pada tegangan $100 \mathrm{~V}$ dan kuat arus sebesar 400 A selama 30 menit. Marker yang di pakai adalah 1000 bp DNA Ladder (Invitrogen). Hasil elektroforesis divisualisasi di bawah sinar ultraviolet dan di foto dengan menggunakan Gel Doc/Bio Rad (Resti et al, 2013).

\section{Sekuensing}

Produk PCR yang diperoleh selanjutnya disekuensing. Data sekuens di edit dengan menggunakan Softwere BioEdit dianalisa dengan Softwere MEGA

Tabel 4.1 : Hasil uji daya hambat Isolat bakteri endofit tanaman Terap terhadap $S$.
6 dan hasilnya dibandingkan dengan sekuens yang ada pada Gene Bank dengan menggunakan fasilitas BLAST search yang terdapat pada situs NCBI (http://www.ncbi.nlm.nih.gov). (Resti et al, 2013).

\section{HASIL DAN PEMBAHASAN \\ Isolasi Bakteri Endofit Kulit Batang Tanaman Terep}

Hasil isolasi bakteri endofit dari kulit batang tanaman terap diperoleh dari hutan wisata desa Sesaot kecamatan Narmada kabupaten Lombok Barat Nusa Tenggara Barat adalah sebanyak 34 isolat bakteri endofit.

\section{Uji Daya Hambat Bakteri Endofit Kulit Batang Tanaman Terep}

Tiga puluh empat isolat bakteri endofit hasil isolasi dari kulit batang tanaman terap(A. elasticus) di uji terhadap 4 jenis bakteri patogen yakni $S$. aureus, $E$. coli, S. typhi dan $P$. aeruginosa.Hasil uji daya hambat yang didapat menunjukkan bahwa bakteri endofit tanaman terap (ET) ,hanya mampu mengahambat $S$. aureus (Tabel 4.1)

Isolat bakteri endofit tanaman Terap hanya mampu menghambat pertumbuhan $S$. aureus . Bakteri S. aureus mempunyai membran plasma tunggal yang dikelilingi dinding sel tebal berupa peptidoglikan. Sekitar 90 persen dari dinding sel tersebut tersusun atas peptidoglikan sedangkan sisanya berupa molekul lain bernama asam teikhoat Di sisi lain, bakteri gram negatif (seperti E. coli) memiliki sistem membran ganda di mana membran pasmanya diselimuti oleh membran luar permeabel. Bakteri ini mempunyai dinding sel tebal berupa peptidoglikan, yang terletak di antara membran dalam dan membran luarnya. (Medigan 2006) 


aureus
\begin{tabular}{|c|l|c|c|c|}
\hline No & $\begin{array}{l}\text { Kode } \\
\text { Isolat }\end{array}$ & $\begin{array}{l}\text { Rata-rata } \\
\text { kali ulangan }(\mathbf{m m})\end{array}$ \\
\cline { 3 - 6 } & & $\begin{array}{l}\text { Bakteri Uji } \\
\text { (S. aureus) }\end{array}$ & $\begin{array}{l}\text { Kontrol + } \\
\text { Cyprofloxacin }\end{array}$ & $\begin{array}{c}\text { Kontrol - } \\
\text { Aquades }\end{array}$ \\
\hline 1 & ETA & 16,33 & 39.33 & - \\
\hline 2 & ETB & 14,16 & 39,33 & - \\
\hline 3 & ETC & 14,83 & 39,33 & - \\
\hline 4 & ETD & 14,50 & 39,33 & - \\
\hline 5 & ETE & 14,83 & 38,33 & - \\
\hline 6 & ETF & 14,83 & 38,33 & - \\
\hline 7 & ETG & 16,83 & 38,33 & - \\
\hline 8 & ETH & 15,33 & 28,33 & - \\
\hline 9 & ETI & 17,33 & 39,00 & - \\
\hline 10 & ETJ & 15,66 & 39,00 & - \\
\hline 11 & ETK & 15,33 & 39,00 & - \\
\hline 12 & ETL & 15,83 & 39,00 & - \\
\hline
\end{tabular}

Luas zona hambat tertinggi adalah pada ETI sebesar $17,33 \mathrm{~mm}$ dan terendah pada isolat ETB sebesar 14,16 mm.dengan mengacu kepada kreteria ukuran zona hambat menurut Menurut Susanto et al., (2012) 11 - 20 termasuk sensitif.Dengan menggunakan standar ini isolat-isolat bakteri endofit pada kulit batang tanaman Terap dapat dikatakan memiliki daya hambat yang kuat atau sensitif.

\section{Identifikasi isolat bakteri endofit kulit batang tanaman Terap}

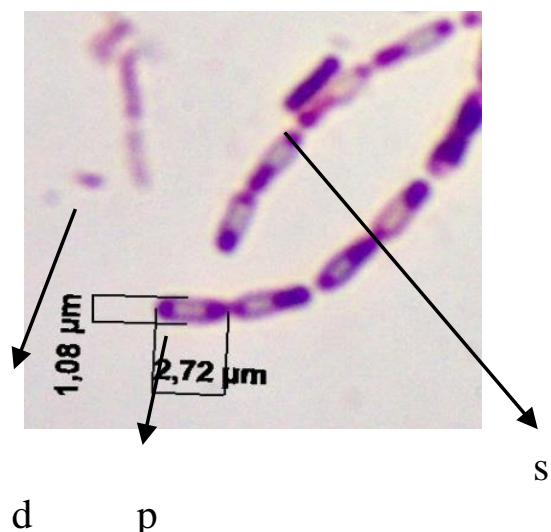

Identifikasi untuk menentukan jenis 12 isolat bakteri endofit kulit batang tanaman terap (A. elasticus) yang mempunyai daya hambat bakteri patogen ini dilakukan dengan cara pengamatan morfologi(cat Gram), uji biokimia dan uji molekuler.

\section{Cat Gram isolat bakteri endofit kulit batang tanaman Terap}

Cat Gram pada bakteri endofit dari kulit batang tanaman terap yang mempunyai daya hambat didapatkan bahwa 12 isolat tersebut adalah tergolong bakteri berbentuk batang dan termasuk bakteri gram positif. Dua belas isolat bakteri endofit kulit batang tanaman terap ,yang di dapat merupakan bakteri Gram positif dengan bentuk basil (batang) pendek ujung tumpul, persegi panjang dan batang panjang berspora dan terlihat ada yang tunggal, bergandengan dan berantai. Salah satu contoh hasil pengecetan gram terhadap 12 isolat bakteri kulit batang tanaman terap pada gambar 1

Keterangan :

d : Diameter satu sel bakteri

$\mathrm{p}$ : Panjang satu sel bakteri

s : Spora bakteri

Gambar 1. Foto hasil cat Gram dengan perbesaran $1000 \mathrm{x}$

\section{Uji Biokimia isolat bakteri kulit batang tanaman Terap}

Uji biokimia bertujuan untuk mengetahui kemampuan isolat bakteri endofit dalam memberikan respon terhadap keberadaan zat atau senyawa tersebut. Uji biokimia pada penelitian ini meliputi uji TSIA (Triple Sugar Iron Agar), uji Simmon sitrat, uji hidrolisis urea, uji motilitas, uji karbohidrat (Glukosa, Sukrosa, Laktosa, Maltosa, Manosa), uji indol, uji katalase, uji hidrolisis pati, uji metil red, dan uji voges-proskauer. Hasil Uji Biokimia dapat dilihat pada Tabel 2 Tabel 2 : hasil Uji Biokimia 12 isolat bakteri endofit tanaman Terap 


\begin{tabular}{|c|c|c|c|c|c|c|c|c|c|c|c|c|c|}
\hline \multirow{2}{*}{\multicolumn{2}{|c|}{ Jenis Uji }} & \multicolumn{12}{|c|}{ ISOLAT bakteri endofit dari kulit batang tanaman terap (Aartocanfus elasstiscus) } \\
\hline & & ETA & ETB & ETC & ETD & ETE & ETF & ETG & ETH & ETI & ETJ & ETK & ETL \\
\hline \multirow{4}{*}{$\begin{array}{l}\mathrm{T} \\
\mathrm{S} \\
\mathrm{i} \\
\mathrm{a}\end{array}$} & Lereng & B & B & B & B & B & B & B & B & B & B & B & B \\
\hline & Batom & A & A & B & A & A & A & A & A & A & A & A & A \\
\hline & Gas & - & - & + & - & - & + & - & - & - & - & - & - \\
\hline & $\mathrm{H}_{2} \mathrm{~S}$ & - & - & - & - & - & - & - & - & - & - & - & - \\
\hline \multicolumn{2}{|c|}{ Simon citrat } & \pm & \pm & + & \pm & \pm & + & - & - & - & - & - & - \\
\hline & Urea & - & - & + & - & - & - & - & - & - & - & - & - \\
\hline & Motility & + & + & + & + & + & + & + & + & + & + & + & + \\
\hline & Glokosa & \pm & + & + & + & + & + & - & \pm & \pm & + & + & + \\
\hline & Laktosa & - & - & - & - & - & - & - & - & - & - & - & - \\
\hline & Sukrosa & \pm & + & + & + & + & \pm & \pm & - & \pm & - & - & \pm \\
\hline & Maltosa & \pm & + & + & + & + & + & \pm & \pm & \pm & + & + & + \\
\hline & Menitol & + & + & + & + & + & + & \pm & + & + & + & + & + \\
\hline & Indol & - & - & - & - & - & - & - & - & - & - & - & - \\
\hline & STRC & + & + & + & + & + & + & + & + & + & + & + & + \\
\hline & MR & - & - & + & + & - & + & - & + & - & + & + & + \\
\hline & VP & + & - & + & + & + & + & + & + & + & + & + & + \\
\hline & Katalase & + & + & \pm & \pm & \pm & \pm & + & + & + & \pm & \pm & \pm \\
\hline & $\begin{array}{l}\mathrm{aCl} \text { grouth } \\
6,5 \%\end{array}$ & - & - & - & - & - & - & - & - & - & - & - & - \\
\hline & Gram & + & + & + & + & + & + & + & + & + & + & + & + \\
\hline & $\begin{array}{l}\text { mbentukan } \\
\text { spora }\end{array}$ & + & - & + & - & - & + & - & + & + & + & + & + \\
\hline & ntuk bakteri & $\begin{array}{c}\text { Basil } \\
\text { tungg } \\
\text { al }\end{array}$ & $\begin{array}{c}\text { Basil ber } \\
\text { gandenga } \\
n\end{array}$ & $\begin{array}{c}\text { Basil } \\
\text { tunggal }\end{array}$ & $\begin{array}{c}\text { Basil } \\
\text { bergandeng }\end{array}$ & $\begin{array}{l}\text { Basil ber- } \\
\text { gandengan }\end{array}$ & $\begin{array}{c}\text { Basil } \\
\text { bergandeng } \\
\text { an }\end{array}$ & $\begin{array}{l}\text { Basil } \\
\text { tunggal }\end{array}$ & $\begin{array}{c}\text { Basil } \\
\text { ber- } \\
\text { gandenga } \\
\text { n }\end{array}$ & $\begin{array}{l}\text { Basil } \\
\text { tunggal }\end{array}$ & $\begin{array}{c}\text { Basil } \\
\text { bergande } \\
\text { ngan }\end{array}$ & $\begin{array}{l}\text { Basil } \\
\text { bergan } \\
\text { dengan }\end{array}$ & $\begin{array}{c}\text { Basil } \\
\text { tunggal }\end{array}$ \\
\hline
\end{tabular}

Keterangan :

A : Asam, B: Basa, (+): Ada atau terbentuk (-): Tidak ada ( \pm ): Ada tapi Lemah

Strac : Hidrolisis Pati, VP: Triple Sugar Iron Agar, MR: Metil Red

\section{PCR Isolat bakteri endofit dari kulit batang tanaman Terap}

Identifikasi spesies bakteri endofit secara molekuler dilakukan dengan beberapa tahapan yaitu isolasi/ ekstraksi DNA, Amplifikasi DNA dengan PCR, Elektroforesis dan Sekuensing. Hasil isolasi DNA dilanjutkan dengan Amplifikasi gen
16S rRNA dengan menggunakan primer universal $63 \mathrm{f}$ dan $1387 \mathrm{r}$ yang spesifik untuk prokariot. Hasil Amplifikasi di elektroforesis pada gel elektroforesis yang diamati di bawah UV transluminator memperlihatkan adanya pita DNA penyandi gen $16 \mathrm{~S}$ rRNA dengan ukuran $\sim 1.5 \mathrm{~kb}$ setelah dibandingkan dengan DNA marker (1 kb DNA leader). Penyandi gen 16S rRNA dengan ukuran \pm 1324 bp setelah dibandingkan dengan DNA marker (1000 bp DNA ladder) (gambar 2). hasil Sekuensing ditunjukan dengan pohon philogenetik (gambar 3)

$\begin{array}{llllllllllllll}M & 1 & 2 & 3 & 4 & 5 & 6 & 7 & 8 & 9 & 10 & 11 & 12\end{array}$

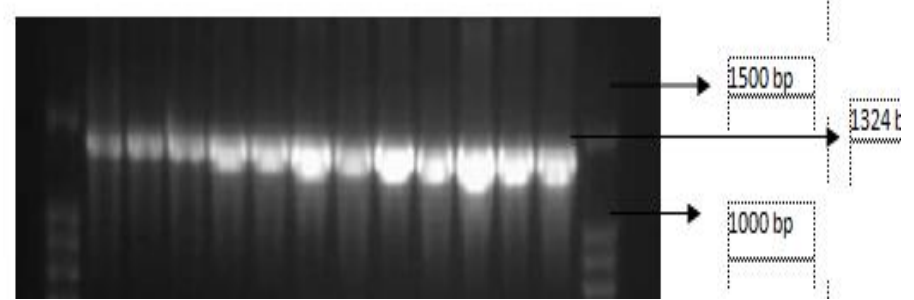

Gambar 2: Hasil PCR 12 isolat bakteri endofit terap,

Marker (m), ETA (1), ETB (2), ETC (3), ETD (4), ETE (5), ETF (6), ETG (7), ETH (8), ETI (9),

ETJ

(10),

ETK

(11),

ETL 
2),

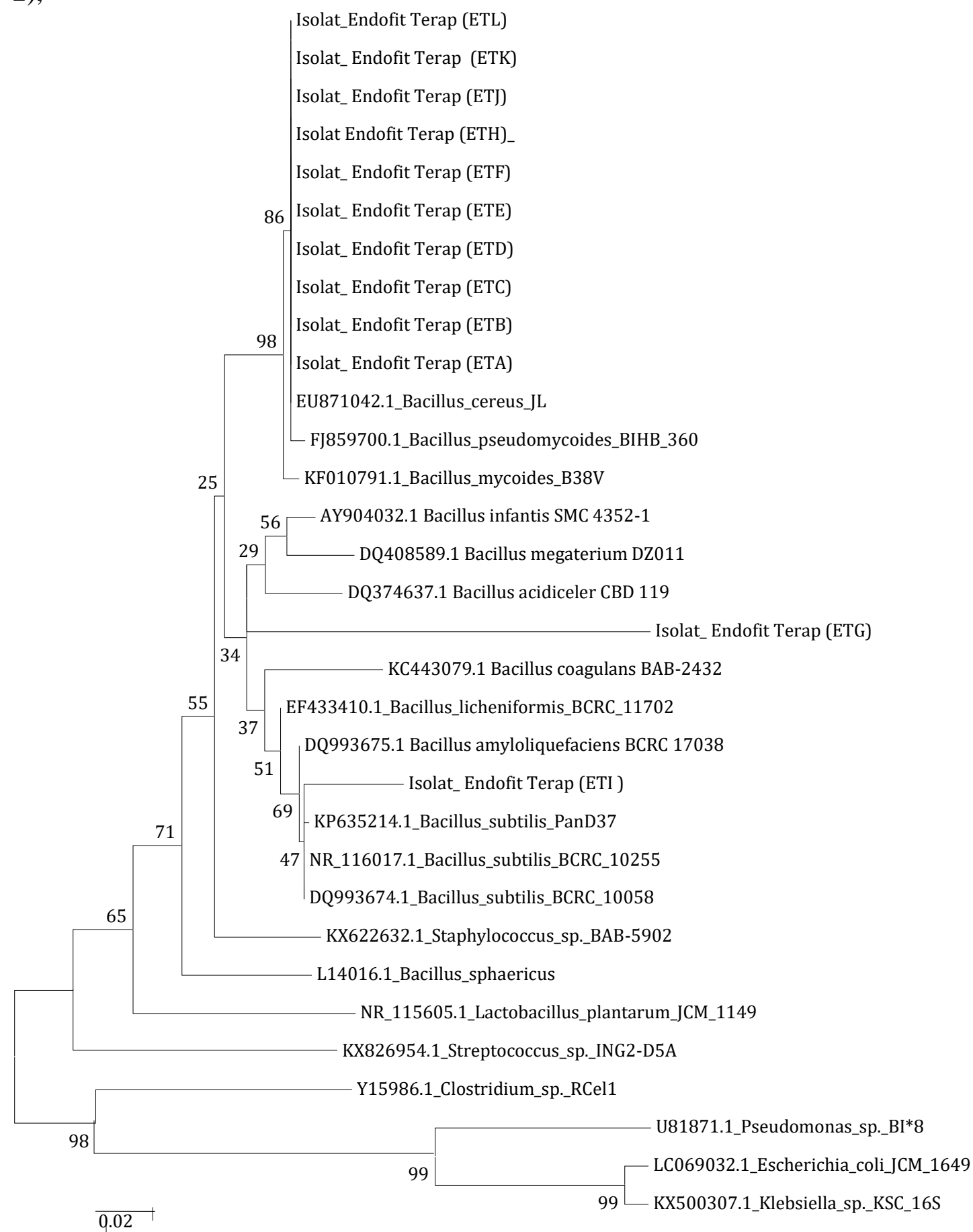

Gambar :Pohon Phylogenetik hasil identifikasi 12 Isolat bakteri endofit dari kulit batang tanaman terap ( A. elasticus) menggunakan softwere MEGA

Berdasarkan gambar 3, terkait hasil analisis filogenetik dengan menggunakan softwere MEGA 6 ( Tamura et al., 2013) diperoleh dua klaster besar yaitu kelompok pertama didominasi oleh genus Bacillus dan Streptococus, sedangkan klaster kedua lebih dominan Clostridium sp. dan Pseodomonas sp. Dua belas Isolasi bakteri 
endofit kulit batang tanaman terap teridentifikasi ada tiga jenis bakteri yaitu B.cereus, B. subtilis dan B. sp. adalah isolat ETA, ETB, ETC, ETD, ETE, ETF, ETH, ETJ, ETK dan ETL tergolong Bacillus cereus. Isolat ETI tergolong Bacillus subtilis sedangkan ETG hanya dapat teridentifikasi sampai ke tingkat genus karena berdasarkan dendogram pada gambar 3 menujunkkan isolat ETG terpisah dengan isolat yang lain dan jarak kemiripan urutan DNA dengan bakteri bacillus dari gene bank lebih besar. (Tamura et al., 2013)

B. cereus merupakan bakteri Gram positif, memiliki warna koloni putih agak krem dan berbentuk batang (bacil). Bakteri ini menghasilkan spora yang berbentuk elips, dimana sporanya hanya terbentuk bila terdapat oksigen dilingkungan sekitar (aerob fakultatif). B. cereus termasuk salah satu organisme mesofilik yaitu dapat tumbuh pada suhu optimal $30^{\circ}-35^{\circ} \mathrm{C}$. Bakteri yang dapat menghasilkan spora lebih tahan terhadap tekanan lingkungan yang ekstrim karena metabolisme selnya terhenti atau dormansi jika berada pada lingkungan yang buruk (Jenson dan Moir 2003).

Beberapa ratus strain $B$. subtilis yang berbeda - beda telah dikumpulkan, diteliti dan di uji antibacterial terbukti strain B. subtillis memiliki potensi untuk menghasilkan senyawa antibiotik dengan berbagai struktur yang menakjubkan (Moszer et al., 2002). Hal ini juga terbukti pada isolat ETG dalam uji daya hambat dapat menghambat pertumbuhan bakteri $S$. aureus. B. subtillis adalah spesies yang paling produktif dari genus Bacillus genomnya menghasilkan $4-5 \%$ dari genomnya menyintesintesis 66 jenis zat antibiotik (Stain, 2005). B. subtilis telah banyak digunakan untuk kegiatan uji genetik dan biokimia dan selama beberapa dekade, bakteri ini dan dinyatakan sebagai bakteri endospora tergolong Gram-positif (Sonenshein et al., 2001)
Hal ini sesuai dengan hasil pengamatan biokimia dan pengamatan hasil cat gram bakteri isolat ETG berbentuk batang dan tergolong bakteri gram positif karena isolat ini berwara ungu dan mempunyai panjang $1,55 \mu \mathrm{m}$ dan lebar atau ketebalan 0,56 $\mu \mathrm{m}$ dan dengan ukuran ini jelas isolat ETG berbentuk batang dengan demikian sudah dapat di pastikan sebagai bakteri gram positif.

\section{Manfaat Keberadaan Bakteri Endofit Bagi Tanaman Inang Dan Bagi Bakteri Isolat Klinik.}

Bakteri endofit dalam jaringan tanaman hidup dan melakukan metabolisme, dalam proses metabolisme bakteri endofit mendapatkan bahan baku dari tanaman tanpa mengganggu proses metabolisme tanaman, sebaliknya hasil sampingan metabolisme yang dikenal sebagai metabolit sekunder sangat bermanfaat bagi kesuburan tanaman dan mencegah terserangnya tanaman padi dari berbagai jenis jamur yang bisa merusak tanaman. terhadap serangan penyakit tanaman.

Mikroba endofit dapat melindungi tumbuhan inang dari serangan patogen dengan senyawa yang dikeluarkan oleh mikroba endofit. Senyawa yang dikeluarkan mikroba endofit berupa senyawa metabolit sekunder yang merupakan senyawa bioaktif dan dapat berfungsi untuk membunuh patogen. Tumbuhan inang menyediakan nutrisi yang dibutuhkan oleh mikroba endofit untuk melengkapi siklus hidupnya. Mikroba endofit memiliki prospek yang baik dalam penemuan sumber-sumber senyawa bioaktif yang dalam perkembangan lebih lanjut dapat dijadikan sebagai sumber penemuan obat untuk berbagai macam penyakit (Backman dan Sikora, 2008).

Lodewyckx et al., (2002) menyatakan bahwa beberapa bakteri endofit menghasilkan enzim deaminase asam 1-aminosiklopropane -1- karboksilik. Enzim tersebut berperan dalam pembentukan etilen pada tanaman. Etilen pada tanaman disintesa ketika tanaman 
menghadapi tekanan lingkungan, baik biotik maupun abiotik. Simbiosis endofit dengan tanaman mampu meningkatkan adaptasi tanaman terhadap lingkungan yang kurang menguntungkan. Kemampuan tanaman bertahan hidup pada tanah-tanah yang terkontaminasi logam berat adalah berkat adanya endofit yang memiliki kemampuan mendegradasi, mengeliminasi, atau menggunakan logam-logam tersebut dalam sistem metabolismenya (Aly et al., 2011)

Pada kasus tertentu keberadaan bakteri endofit juga mampu berperan sebagai 'disease-suppressive soils'. Saat ini Bacillus mojavensis merupakan bakteri yang dipatenkan sebagai bakteri endofit yang mempunyai peran penting dalam melindungi tanaman dari serangan patogen penyebab penyakit sekaligus meningkatkan pertumbuhan tanaman dalam kondisi kering (drought tolerance) (Bacon dan Hinton, 2002).

\section{Prospek Mikroba Endofit kulit batang Terap Dalam Penemuan Senyawa- Senyawa Bioaktif}

Kim et al. (2002) melaporkan bahwa bakteri endofit Bacillus lentimorbus menghasilkan senyawa alphadan betaglucosidase yang bersifat anti jamur sehingga mampu menghambat pertumbuhan patogen Botrytis cinerea. Bakteri tersebut juga digunakan untuk melindungi tanaman kentang dari infeksi Fusarium sambucinum, karena adanya senyawa volatile yang bersifat racun bagi jamur tersebut (Sadfi et al.,2001); Chérif et al., 2003). B. cereus yang umum ditemukan sebagai bakteri endofit pada kapas (Gossypium hirsutum), jagung manis (Zea mays), dan tanaman jeruk (Citrus spp.) ternyata mampu menghasilkan chitinase untuk mendegradasi dinding sel jamur patogen seperti $F$. sambucinum (Sadfi et al., 2001),

Bakteri endofit yang berhasil di isolasi dari kulit batang tanaman terap teridentifikasi sebagai $B$. cereus dan B.subtilis mempunyai kemampuan menghambat pertumbuhan bakteri S.aureus. Kemampuan ini disebabkan karena bakteri mampu menghasilkan metabolit sekunder yang dapat menghambat pertumbuhan bakteri potegen ini. Dengan demikian senyawa metabolit sekunder yang dihasilkan oleh bakteri endofit terap ini adalah flavonid. Artocarfus banyak menghasilkan senyawa golongan terpenoid, flavonoid, dan stilbenoid. Keunikan struktur metabolit sekunder pada Artocarpus menghasilkan efek yang sangat luas, antara lain sebagai anti bakteri (Khan et al., 2003), anti fungal (Jayasinghe et al., 2004) dan anti diabetes (Nasution, 2013). Menurut Tan dan Zou (2000), bakteri endofit dapat menghasilkan senyawa bioaktif yang karakternya mirip atau sama dengan senyawa yang diproduksi oleh tumbuhan inangnya.

S.aureus yang merupakan patogen utama bagi manusia. S.aureus bersifat koagulase positif, yang membedakannya dari spesies lain. S.aureus menyebabkan pneumonia, meningitis, endokarditis dan infeksi kulit S. aureus. Dapat menyebabkan keracunan makanan, gejala keracunan biasanya cepat dan akut, tergantung pada daya tahan tubuh dan banyaknya toksin yang termakan. Jumlah toksin yang dapat menyebabkan keracunan adalah $1,0 \mu \mathrm{g} / \mathrm{gr}$ makanan. Gejala keracunan ditandai oleh rasa mual, muntah-muntah, dan diare yang hebat tanpa disertai demam (Jawetz, et al., 2005).

Berdasarkan uji daya hambat 12 isolat bakteri endofit kulit batang tanaman terap memiliki kemampuan untuk menghambat pertumbuhan bakteri isolat klinik S.aureus dengan kenyataan ini bakteri endofit dari hasil penelitian ini dapat dikembangkan untuk dijadikan sebagai sumber senyawa antibakteri untuk mengobati berbagai jenis penyakit yang diakibatkan oleh bakteri S.aureus. 


\section{KESIMPULAN}

Berdasarkan hasil penelitin dan kajian literatur serta diskusi maka dapat di simpulkan bahwa .

1. Isolat bakteri endofit pada kulit batang tanaman terap mampu menghambat pertumbuhan bakteri $S$. aureus

2. Dua belas jenis isolat bakteri endofit pada kulit batang tanaman Terap yang mempunyai daya hambat tersebut teridentifikasi sebagai $B$. cereus, $B$. subtilis dan Bacillus Sp.

3. Bakteri endofit Bacillus cereus, Bacillus subtilis pada kulit batang tanaman terap dapat dikembangkan sebagai senyawa antibakteri untuk mengobati berbagai penyakit yang di timbulkan oleh bakteri isolat klinik $S$. aureus

\section{DAFTAR PUSTAKA}

Adawiah. 2006. Identifikasi Bakteri dan Produk Fermentasi Rayap Kayu Kering. Pertanian Universitas Halvoleo. Kendari.

Aly A. H., A. Debbab, and P. Proksch. 2011. Fungal endophytes: unique plantinhabitants with great promises. Appl Microbiol Biotechnol. 90:1829-1845

Backman PA, Sikora RA. 2008. Endophytes: an emerging tool for biological control. Biol Control. 46(1):1-3. doi:10.1016/j.bio control.2008.03.009

Bacon CW , and Hinton DM. 2006. Bacterial endophytes : the endophytic niche, its occupants, and its utility. Gnanamanickam SS, editor Plant-Associated Bacteria. Netherland :Springer

Beck, H.C, Hansen A.M., \& Lauritsen, F.R., (2003) Novel pyrazine metabolites found in polymyxin biosynthesis by Paenibacillus polymyxa. FEMS Microbiol Lett 220: 67-73.
Brown, A. 2001. Microbiological Applications Lab Manual. 8th Ed. The McGraw-Hill Companies, New York.

Castillo, U.F., G.A. Strobel, E.J.Ford, W.M. Hess, Heidi Porter, J.B.Jensen, Heather Albert, Richard Robinson, M.A. Condron, D.B. Teplow, Dennis Steven, and Debbie Yaver. 2003. Munumbicins, wide-spectrum antibiotics produced by Streptomyces NRRL 30562, endophytic on Kennedia nigricans. Microbiology.148. pp.2676.

Cappuccino, N., MacKay, R. and Eisner, C. 2001. Spread of the invasive alien vineVincetoxicum rossicum: tradeoffs between seed dispersal and seed quality./Am. Midl. Nat. 148: 263/ 270.

Chirife, J., Herszage, L., Joseph, A, \& Kohn, E. S., 1983, In Vitro Study of Bacterial Growth Inhibition in Concentrated Sugar Solutions: Microbiological Basis for the Use of Sugar in Treating Infected Wounds, Journal Antimicrobial Agent and Chemotherapy, 766773.

Hakim , A. dan Jufri, A. W., 2011. Aktifitas Anti Malaria dan Analisis Metabolit Sekunder Kayu dan Kulit Batang Artocarpus odoratissimus blanco. Fakultas Keguruan dan Ilmu Pendidikan Jurusan FMIPA: Universitas Mataram

Heyne, K.,1987.Tumbuhan Berguna Indonesia. Badan Litbang Kehutan Jakarta

Jayasinghe, L., Balasoori, B.A.I.S., Padamini,W.C., Fujimoto, Y., (2004) Generly chalcone derivatives with antifungaland radical scavenging propertis from the leaves of Artocarfus 
nabilis, Phyochemistery, 65, 1287-1290

Jawetz M; Adelberg's. 2005. Mikrobiologi Kedokteran edisi 23. Alih Bahasa: Huriwati Hartanto dkk. Jakarta, Penerbit Buku Kedokteran ECG

Jenson I, Moir CJ (2003) Bacillus cereus and other Bacillus species. Ch 14 In: Hocking AD (ed) Foodborne microorganisms of public health significance. 6th ed, Australian Institute of Food Science and Technology (NSW Branch), Sydney, p. 445-478

Khan, M.R., Omaloso,A.D.,Kihara, M.,(2003) antibacterial activity of Artocarfus heterophlus, Fitoterapia 74,501-505

Kim, K. J. A.; Y. J. Yang, and J. Kim. 2002. Production of alphaglucosidase inhibitor by betaglucosidase inhibitor producing Bacillus lentimorbus B-6. Journal of Microbiology and Biotechnology 12: 895-900.

Lodewyckx, C . J. Vangronsveld, F. Porteous, E. R.B. Moore, S. Taghavi, M.Mezgeay, and D. van der Lelie. 2002. EndophyticBacteria and Their Potential Applications.

Masyhud. 2010. Lokakarya Nasional Tanaman Obat Indonesia (TOI). Badan Litbang Kesehatan. Jakarta.

Moszer, I., Jones, L.M., Moreira, S., Fabry, C., and Danchin, A. (2002) SubtiList: the reference database for the Bacillus subtilis genome. Nucleic Acids Res 30: 62-65.

Madigan, MT., Martinko, JM. And Parker, J.(1999) Biology of Microorgansm Eight Edition Prentice Hall Intemational, Inc.New York, San Francisco, Boston USA

Nasution, R. 2013. Isolasi dan Penentuan Struktur Senyawa Steroid dari
Daun Tumbuhan Kulu (Artocarpus camansi: Sukun Berbiji) yang Bersifat Antidiabetes. Disertasi. Medan: Universitas Sumatra Utara Raihana,N. 2011. Profil Kultur dan Uji Sensitivitas Bakteri Aerob dari Infeksi Luka Operasi Laparatomi di Bangsal Bedah RSUP DR. M. Djamil Padang. Artikel. Program Pascasarjana Universitas Andalas Padang.

Resti Z, Habazar T, Putra DP, Nasrun. 2013. Skrining Dan Identifikasi Isolat Bakteri Endofit Untuk Mengendalikan Penyakit Hawar Daun Bakteri Pada Bawang Merah. J. HPT Tropika. ISSN 1411-7525. Vol. 13, No. 2: 167 178.

Sadfi, N.; M. Cheri; I. Fliss; A. Boudabbous, and H. Antoun. 2001. Evaluation of bacterial isolates from salty soils and Bacillus thuringiensis strains for the biocontrol of Fusarium dry rot of potato tubers. Journal of Plant Pathology 83: 101-118.

Sardiani Neni, Litaay Magdalena, Budji Risco G., Priosambodo Dody, Syahribulan, Dwyana Zaraswati. 2015. Potensi Tunikata Rhopalaea Sp Sebagai Sumber Inokulum Bakteri Endosimbion Penghasil Antibakteri; 1. Karakterisasi Isolat. Jurnal Alam dan Lingkungan Vol.6 No.11.

Sonnenschein AL, Losick R, Hoch JA (1993) Bacillus subtilis and Others Gram-Positive Bacteria: Biochemistry, Physiology and Molecular Genetics. AmericanSociety for Microbiology, Washington, DC

Steven K. Alexander, Dennis Strere, Mary Jane Niles et al. 2004. Laboratory Exercises in Organismal and Molecular 
Microbiology. Mc Graw Hill. USA.

Stein T. (2005) Bacillus subtilis antibiotics: structures, syntheses and specific functions. Mol Microbiol 56: 845-857

Simanjuntak P, Bustanussalam, Otovina DM, Rahayuningsih M, Said EG. 2004. Isolasi dan identifikasi artemisinin dari hasil kultivasi mikroba endofit dari tanaman Artemisia annua. studi mikroba endofitik tanaman ( Artemisia spp). Majalah Farmasi Indonesia $15(2): 68-74$

Strobel, G.A. 2002. Microbial gifts from rain forests. Can. J. Plant Pathol., 24: 14-20

Susanto, D. Sudrajat dan R. Ruga. 2012. Studi kandungan bahan aktif tumbuhan meranti merah (Shorea leprosula Miq) sebagai sumber senyawa antibakteri. Mulawarmnan Scientifie 11(2): 181-190.

Tan, R.X., and W.X. Zou. 2001. Endophytes : a rich source of functional metabolites. Nat. Prod. Rep. 18: 448-459.

Tamura K. and Nei M. (1993). Estimation of the number of nucleotide substitutions in the control region of mitochondrial DNA in humans and chimpanzees. Molecular Biology and Evolution 10:512-526.

Tamura K., Stecher G., Peterson D., Filipski A., and Kumar S. (2013). MEGA6: Molecular Evolutionary Genetics Analysis version 6.0. Molecular Biology and Evolution30: 2725-2729. 